\title{
Origins and Powers of the New Rich
}

Compiled and Commented Analysis

\section{Camille Bondois}

\section{(2) OpenEdition}

\section{Journals}

Édition électronique

URL : http://journals.openedition.org/chinaperspectives/1403

DOI : 10.4000/chinaperspectives. 1403

ISSN : 1996-4617

Éditeur

Centre d'étude français sur la Chine contemporaine

Édition imprimée

Date de publication : 15 janvier 2007

ISSN : 2070-3449

\section{Référence électronique}

Camille Bondois, "Origins and Powers of the New Rich », China Perspectives [En ligne], 2007/1 | 2007,

mis en ligne le 08 avril 2008, consulté le 28 octobre 2019. URL : http://journals.openedition.org/

chinaperspectives/1403; DOI : 10.4000/chinaperspectives.1403

(C) All rights reserved 
ル

This section, prepared by the Asia Centre (www.centreasia.org), draws mainly on the press in Chinese, aiming to reflect the point of view of the People's Republic of China on international questions and issues related to Greater China.

\section{Origins and powers of the new rich}

\section{Compiled and commented by Camille Bondois based on:}

- Unsigned article, "Private business people acquire more influence in China," The People’s Daily, 13 August 2006

- Han Fang Ming, "The new social responsibilities of the business community," Nanfang Zhoumo, 26 October 2006

- Lie Yin, "90\% of wealthy people in China are the children of top civil servants," Singtao Daily, 19 0ctober 2006

- "China's first national survey of the 'new middle class,"” 9 September 2006

$\mathrm{N}$ early thirty years after the beginning of China's economic opening-up, the fruits of the reforms launched by Deng Xiaoping are becoming apparent among the people themselves: China now has a significant number of very rich people, who regularly make headlines in the Chinese and overseas press. Every year, in China and abroad, new assessments and studies are published on this new social class that, thirty years before, hardly existed at all within the Chinese social system, and had no political legitimacy.

Who are they? How have they become so rich, so quickly? What power do they really exercise within society? What commitments do they have? Those are the questions being raised by the Chinese press, which is at the same time fascinated by, and critical of this section of the population. The new rich are the product of economic development, reflecting the most conspicuous aspects of growth and its most perverse and obscure aspects as well.

\section{The rise of the private sector}

Chinese journalists seem of one mind in linking wealth with the rise of the private sector. Deng's reforms enabled private enterprises to proliferate and flourish in a now favourable environment. As The People's Daily reminds its readers, in the nineteen seventies the word "private" was still taboo, being considered as tainted with capitalism. And yet, gradually, the attitude towards the private sector has evolved, to the point of being completely reversed. In the official documents of the Chinese Communist Party (CCP), the private sector was seen at first as "a supplement to the state sector", then as "an important part of the economy" and finally as "a basic element in the economic system". So the private sector has now acquired real legitimacy: the Party and consequently the government can no longer ignore the private sector's contribution to growth, among the clearest signs of which was Jiang Zemin's "Theory of the Three Represents," first enunciated in 2001.

The greatest number of Chinese businessmen to have made their fortunes are to be found in the key sectors of Chinese development. Finance, property, foreign trade and construction have been particularly profitable.

From this burgeoning private sector, a number of individuals have clawed their way upwards; a class of wealthy people has gradually emerged, seeking to make its voice heard on the political stage. It is a class that has become an essential and influential element within society and the political class.

\section{Top leaders' children}

Yet, while the private sector has enabled some to make their fortunes, the Hong Kong newspaper Singtao Daily reveals that actually, few are self-made men. Indeed, the paper has published a survey carried out by agencies within the Research Centre of the State Council, the Research Centre of the Party School and the Chinese Academy of Social Sciences (CASS). The survey concludes that, of the thousands of rich Chinese people, $90 \%$ are the offspring of senior officials.

More specifically, The International Manager has published a report showing that, in March 2006, 27,310 people had capital assets worth over 50 million yuan, and that 
3,220 people had amassed fortunes worth over 100 million yuan. Of the latter, 2,932 are the children of senior government officials.

These wealthy people live mainly in the eight most flourishing Chinese provinces, among them Canton (1,566 people), Shanghai (225 people), Peking (195 people), Jiangsu (172 people), Shandong (141 people) and Liaoning (79 people).

Not only have the new rich amassed a total capital of nearly 200 billion yuan but they also occupy the top corporate jobs in the key sectors of China's burgeoning economy: finance, real estate, construction and foreign trade.

Furthermore, the survey reveals that the biggest enterprises in the country are managed by the children of top officials. For example, in Canton, the 20 leading real estate companies belong to the offspring of government officials. In Shanghai, for nine out of the ten largest real estate companies, it is the same story. In Jiangsu, the 22 biggest real estate companies and the 15 biggest construction companies belong to people whose fathers occupy or have occupied posts such as Vice-Governor of the province, or provincial deputy to the National People's Congress, or Vice-Secretary of the Provincial Committee of the Communist Party, or President of the Provincial Court ... the list goes on.

According to the Singtao Daily, which speaks of a class that is bureaucratic and capitalist at the same time, wealth depends on the power wielded by the family, whether it is legal, illegal or “apparently legal” (有合法的, 有非法的,有合法下的非法所得). In present-day China, some posts are particularly prized and are good ways of acquiring wealth: exercising control over imports and exports or over foreign investment, managing bank lending, assigning public works contracts, or controlling financial speculation.

To land a contract or secure planning permission for a building project, it is essential to have political support. Similarly, local officials are dependent on financial support and investment from private entrepreneurs. There is thus no clear dividing line between political power and economic power.

\section{The development of special interest groups and the battle for influence}

This mechanism for generating profits, in which public and private affairs are intermingled, has favoured the formation of special interest groups aimed at exerting influence over political decision-makers and legislators.
Special interest groups are so widely spread in China that the authorities, since the Sixth Plenum of the Sixteenth Congress of the Communist Party, have adopted measures designed to prevent them from destroying the social order. Singtao Daily cites an article in the official newspaper Liao Wang dividing interest groups into three main categories. The first category has to do with foreign trade. It brings together the National Chamber of Commerce and the China Association of Enterprises with Foreign Investment. The article shows that this group's members go in for extensive lobbying within the political class. They "buy" or make use of the children of government officials; they recruit the leaders of departments, civil servants, as "consultants" to official bodies; they finance research centres for ministries and commissions, providing experts who will fight for their interests. They use all possible channels to exert influence upon political decision-makers and to bend the legislation to their own ends.

The second category is of the very large state enterprises enjoying monopoly status in the key fields of finance, energy, transport and construction. They seek to defend their advantages by recruiting or bribing politicians or intellectuals as spokesmen, so as to influence and control public discourse in their favour.

The third category is the heads of private enterprises in various fields of activity. They scramble for posts as deputies to the National People's Congress or to the Chinese People's Political Consultative Conference. Their aim is to make names for themselves on the political stage. Those who fail to land these posts will pay experts to exert corrupt influence on their behalf over the political decision-makers.

Thus, in 2005, as The People's Daily points out, among the 2,900 deputies of the National People's Congress, more than 200 were private businessmen.

Private entrepreneurs are now seeking to make themselves heard, and to influence decision-making and legislation; they are demanding political power.

And even though $\mathrm{Hu}$ Jintao and Wen Jiabao do attempt, as part of their policy of adjustment and control, to limit the influence of these interest groups, which unite politicians and businessmen around their shared interests, their efforts appear fruitless faced with the enormity of the phenomenon. In trying to restrain the surging property prices, as the Singtao Daily emphasises, Hu Jintao caused a chain reaction: the real estate company bosses joined forces with civil servants, the media and the research centres to swamp public discourse on the real estate problem and distort the regulation policy. 
U

$\geq \quad$ Yet, while the Singtao Daily uncovers the darker aspects of Chinese power, the corruption and the struggle for influence, it nonetheless issues a warning to $\mathrm{Hu}$ over his adjustment policy: the special interest groups are the by-products of growth, and seeking to stop their activities would amount to renouncing the reforms and reversing the course of development. The consequences for China, economic and political, could be disastrous.

\section{Social responsibility}

Opening up in parallel with these political and economic rivalries is a path still mostly unexplored among China's private enterprises and the new rich: social commitment.

Last October, a meeting was organised to found the China Corporate Social Responsibility (CSR) Alliance. The participants included IBM and Nokia, among the multinationals established in China and Chinese firms such as China Merchants Bank, TCL and the insurance company Ping An.

This unprecedented event, as covered by Nanfang Zhoumo (Southern Weekend), gives voice to the social commitment of prosperous Chinese companies, on the model of the charitable networks set up by big international companies (for example, the Global Leadership Network in which IBM and General Electric are prime movers).

Unlike those CEOs who meet to play golf, this alliance of businesses has a far more humane vocation: for while China now boasts a great number of rich and powerful companies, its social problems are no less numerous, as Nanfang Zhoumo indicates, raising the problem of the persistent lack of social legislation. Chao Fangming deplores the fact that, for example, some measures offering sustainable development are relatively overlooked by companies, measures such as saving energy resources and protecting the environment, while others are still ignored: he says that the right to work is scorned across most of the country and even economists show scant interest in it.

Even so, Nanfang Zhoumo, while it does see this alliance as a starting point, is still uncertain: what will Chinese enterprises really achieve in this area? Will their desire to act bear any fruit? Is it just one more bluff, so that firms can burnish their images?

\section{Conclusion}

Over these past thirty years, China's private entrepreneurs have developed from the embryonic stage to a maturity that is now encouraging them to redefine their role in society.
The Chinese state must now take account of a new social and political force: the businessmen and especially those who have become wealthy. Yet, the social composition of this new class is very ambiguous. These entrepreneurs have frequently sprung from the families of senior government officials, families with undeniable political power. So those in power, economic or political, are interdependent, which has major implications for China: the interest groups form complex networks linking civil servants, intellectuals and businessmen.

With the support of these interest groups, the businessmen having for a long time been excluded from the political arena are reckoning on making their voices heard, on exerting strong influence over political decisions and tilting the legislation towards their interests.

In parallel with these struggles for power, some enterprises are seeking to make a social contribution. In reaction to mounting criticism for their lack of responsibility to society, they are joining forces to devise a model for commitment, so that their wealth might benefit the whole community. Will this group succeed in making its voice heard?

The ultimate question might be this: does the development of the private sector and the creation of special interest groups mark the birth of new forms of power in China, forms that might come to rival the monopolistic powers of the Communist Party? 